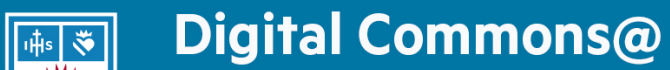

Loyola Marymount University

LMU Loyola Law School

\section{Cities and the Environment (CATE)}

\section{Community Gardening Works! American Community Garden Association's 32nd Annual Conference August 18-21, 2011, New York, NY}

Nancy Falxa-Raymond

USDA Forest Service, njfalxaraymond@fs.fed.us

Carolin Mees

mees architecture, mees.carolin@gmail.com

\section{Recommended Citation}

Falxa-Raymond, Nancy and Mees, Carolin (2012) "Community Gardening Works! American Community Garden Association's 32nd Annual Conference August 18-21, 2011, New York, NY," Cities and the Environment (CATE): Vol. 5: Iss. 1, Article 2.

Available at: https://digitalcommons.Imu.edu/cate/vol5/iss $1 / 2$

This Editor's Introduction is brought to you for free and open access by the Center for Urban Resilience at Digital Commons @ Loyola Marymount University and Loyola Law School. It has been accepted for inclusion in Cities and the Environment (CATE) by an authorized administrator of Digital Commons at Loyola Marymount University and Loyola Law School. For more information, please contact digitalcommons@lmu.edu. 
Community Gardening Works! American Community Garden Association's 32nd Annual Conference August 18-21, 2011, New York, NY 
On August 18-21, 2011 approximately 350 people came together at Columbia University in New York City for the American Community Gardening Association's $32^{\text {nd }}$ Annual National Conference, "Community Gardening Works!" This special issue of Cities and the Environment (CATE) contains selected proceedings of the conference, including a variety of research on the history, current practice, and future of community gardening and urban agriculture.

The American Community Gardening Association (ACGA) was founded in 1979 in order to help community gardening programs and gardeners share their limited resources and thereby benefit from each other's experience and expertise. Part of the ACGA mission is to promote the formation and expansion of national and regional community gardening networks, as well as to encourage research on the impact of community greening in support of those networks.

The ACGA's Annual Conference allows community gardeners from across the nation and the world to share and disseminate best practices relating to community gardens, advocate for appropriate policies to support community gardens, provide networking opportunities for professionals and others involved in the field, and continue to foster the community garden movement.

The 2011 conference included interactive, educational, and practitioner-led workshops on topics including: Food, Health, and Nutrition; Youth and Adult Education; Government and Advocacy; Economic Development and Urban Agriculture; Sustainability; Horticulture and Ecology; and Organizational and Community Development. Following the workshops, New York City environmental stewardship organizations led local tours of community gardens, neighborhoods, parks, and urban food systems. Conference presenters and attendees included academic researchers, gardeners, educators, environmental advocacy groups and non-profits. All who attended the conference walked away more knowledgeable and inspired to share what they learned with their communities.

We are proud to deliver this special issue of CATE in order to share some of the research presented at the 2011 ACGA conference with a broader audience. CATE, as a freely accessible online forum for urban environmental researchers and practitioners, was a natural choice for this special issue topic, and we would like to thank the CATE staff for their guidance and support. Both ACGA and CATE support the exchange of ideas in support of positive urban transformation and are committed to reaching a broad membership.

This special issue explores the role of community gardens as an essential part of a city's green infrastructure. Some authors have taken a historical look at the place of community gardens in urban ecology and social movements, including the use of Supplemental Nutrition Assistance Program (SNAP) benefits for gardening. Others look towards an urban future that combines green and grey elements of design in a way that makes cities more equitable, healthier places to live. This issue also presents research in developing new methods for quantifying agricultural production and modeling food systems in urban areas. Finally, the politics of urban agriculture planning are addressed with an eye towards the future of community gardening.

Community gardening improves people's quality of life by providing a catalyst for neighborhood and community development, stimulating social interaction, encouraging self-reliance, beautifying neighborhoods, producing nutritious food, reducing family food budgets, conserving resources and creating opportunities for recreation, exercise, therapy and education. We'd like to 
thank the ACGA conference planning committee for their tireless work to create such an exciting event in support of gardeners throughout the country and worldwide. We hope that this special issue will attract new ideas and interest in the politics, practice, and benefits of community gardening for a future sustainable urban development.

Nancy Falxa-Raymond

Northern Research Station

USDA Forest Service

New York, NY
Carolin Mees

mees architecture

New York, NY 